\title{
EDITORIAL
}

\section{On Visions, Short and Long}

Looking into the future is a risky activity, as prophets and seers have found to their cost throughout the ages: too short a time-span and one faces the uncomfortable situation of having one's visions contradicted by a disrespectful reality; too long a time-span and the natural impatience of the profane tends to undermine the standing of even the most enthusiastic of visionaries.

Yet, for the universities of the world, risky though this activity is, it is also necessary. It is necessary for the simple reason that despite the pressure bearing down on them from all quarters to be 'pertinent' - a horrid Gallicism of the term 'relevant' - universities are essentially institutions which function in the long term. Or, to be more precise, they work to a time-scale that is largely independent of the rhythm imposed on politics by the ballot box or the delivery date-lines to which industry claims to work. It is a time-scale determined by the pace of the individual disciplines, by rhythms of projects in hand and by the nature of the knowledge universities are entrusted with purveying and elaborating.

Not only are the disciplines very different in their operational time-scales from time as perceived by the external world. They tend to be very different between disciplines within the university. In short, to take a central point developed in his article by Hans van Ginkel, if the university is a place of creativity, that creativity is very far from being homogeneous or subject to the same pace either of acquisition or of maturation. The time-scale to which historians do their work is very different from that which governs the creativity of the physicist. The former may well take upwards of a decade to produce his or her master piece of research and erudition. The latter over the same period may well have authored upwards of a hundred papers conjointly with his or her colleagues. Whether, in the words of the late American versifier, Ogden Nash, it is simply a case of the 'one maturing late, or the other rotting early' is certainly a value judgement best left to the adepts of these two fields!

The university is, indeed, a place where creativity is one of its basic tools. Excellence that is, originality of mind plus track record and creativity as one aspect of that overall quality, commonly recognized - is its gold coin of exchange and repute. But the university is also, to use a Biblical analogy, a house with many mansions and if they all seek to foster excellence by means, inter alia, of creativity, their respective capacity to do so is far from being the same within a stipulated period.

\section{LOOKING AHEAD: A VITAL LEADERSHIP EXERCISE!}

By looking into the future, the university - or for that matter, its leadership - is far from indulging itself in pleasing speculation or in exercises of wishful thinking. On the contrary, both are engaging in a fundamental activity which permits each and every one of the basic intellectual building blocks, which are the disciplines, be they mature, nascent or in process of acquiring a prototypical identity and cohesion, to contribute to an assessment of their house independently of the specific time frame in which they individually function and evolve.

There are other reasons for seeking to identify various possibilities, scenarios or situations which may emerge over the coming quarter century. The first of these is, of course, that the university, like very large tankers, requires a good look-out in order to be able to change course and to have time to complete the manoeuvre above all when, as is not unusual these days, the Ship of Learning has to plot its course within narrow financial straits, in both senses - nautical and financial - of that word. The second reason for entertaining a long-term vision is perhaps rather more devastating. Without it, institutional administration is simply a form of short-term crisis management at best, or muddling through at worst. And the shorter the time or the more pressing the need to decide - which is the classic definition of crisis the less easy it is to reconcile conflicting interests, though it may be possible to put a gloss of learning, apply dubious theory and attach a pseudo-scientific vocabulary to the different types of arbitrariness that haste and expedition call forth.

A long-term vision may be the work of a singularly talented individual. But because it is presented as long term, it can, for that self-same reason, be discussed, refuted, refined and restated - all activities that are as intrinsic to academia as they are to democracy. One may build consensus around a vision and from a shared vision one may seek to build the intermediary stages between what is now towards what might be in the future. The short term, like the imminent prospect of hanging, may indeed concentrate the mind wondrously. But, it tends also to favour the agents of the 'quick fix' and involves, essentially, closing options rather than opening them.

\section{MAJOR PERSPECTIVES}

In examining what the university of the 21 st century might have to accommodate in the way of social pressures and technological change, there are possibilities beyond imagining. The 
'internationalization' of higher education, the speeding up of the intensity of exchange of information are, of course, trends already evident, both in terms of computer-based networks, in the burgeoning of mobility programmes for students and staff and in the laying down of mobility and exchange agreements between individual institutions, nations and members of the emergent trading blocs which, doubtless, will be one of the governing features of the coming century. In this sense, many of the contributions in this issue are extrapolations from already visible developments. Such an approach forms the basis of the articles by van Ginkel and Martins Romêo. Others are focused less on the task of extrapolation than an analysis of the forces, some national, others global, some technological, others more impelled by societal considerations, which have contributed to bringing about the present degree of 'internationalization' within a particular nation. Such a perspective, which is both comparative and historic, emanates from the contributions from Drs Nagai and Kobayashi.

What emerges from this series of articles which formed the basis of the Regional Meeting of the International Association of Universities in Japan, is that the university of the $2 \mathrm{lst}$ century, for better or for worse, will not be able to avoid (even supposing it had the desire) being both in the world and of it. This concept, once used by the sociologists of 16 th century religious movements to describe the self-perception of certain Protestant sects, is singularly useful in enabling us to understand one of the major long-term shifts in the place of the university in society and one which, because we are close to it and because it is so integral a part of contemporary ideology and values, we tend to take for granted. Indeed, it is very much part of one of today's orthodoxies, one to which society has recourse when it seeks to exercise control over the university. The term 'elitist', for instance, once used to describe those qualities attaching to the nation's most talented and to the priority that higher education set upon their education and training, has taken on other overtones: that of being taken up with matters that are not the concern of the ordinary citizen, of being 'detached' from the world or, worse still, of being 'irrelevant'. It is now the duty of the university not merely to be 'relevant' - and relevance, like treason, is largely a matter of dates - but to be seen to be relevant.

\section{THE UNIVERSITY AS A NATURAL SITE FOR THE LONG- TERM PERSPECTIVE}

It has not always been so. Indeed, for most of the 19th century and on into the present era that is now closing, the university was viewed as a transcendental institution, seeking to preserve a sense of identity, continuity and learning whose quintessence consisted precisely in being above immediacy, devoted to those enduring and continuing aspects of human endeavour which remained after regimes had decayed and fashion passed on. The university was, to revert to the earlier religious analogy, in the world, but not of it. One may argue that such a concept of the university might indeed be sustainable in times when, at most, no more than 3 per cent of an age group entered it and especially since virtually all who did so could, by dint of their statistically exceptional nature, count on a job at the end. The point would be well taken. Even so, the prime feature of the university was not its relevance to society, so much as its detachment from society. Through its detachment came its ability naturally to entertain a view on society and its own part in it, sub specie aeternitatis - that is, from a long-term perspective. The other point that could be made is, of course, that its prime virtue was not to respond to change so much as to integrate change - which was viewed as ephemeral - into the long term and the enduring. Put succinctly, the university was the major institution through which society, before an age of planning, viewed itself in a long-term perspective.

That taking a long-term perspective is seen as risky would appear to reflect, of course, a lack of confidence in even short-term social planning which is one of the more desolating characteristics of our present times. But it also reflects the degree to which entertaining a long-term perspective has not merely passed from the university, but also that the university is itself expected to concentrate on the here and now on pain of being accused of 'elitism' or 'irrelevance'. It is precisely for this reason that more than ever, higher education should not abandon a task that it has long performed, and of which society today stands sorely in need.

Guy Neave 